\title{
ABDOMINAL GUNSHOT WOUND TO PREGNANT WOMAN AT 22 WEEKS OF GESTATION: A CASE REPORT
}

\author{
22 HAFTALIK GEBEDE ABDOMINAL ATEŞLI SILAH YARALANMASI: OLGU SUNUMU
}

\author{
Tolga KARACAN Cemile ILHAN Mustafa Üner KARACAOĞLU Hikmet KOÇER Taner Abdullah USTA
}

\begin{abstract}
Bağcılar Eğitim Ve Araştırma Hastanesi Kadın Hastalıkları Ve Doğum Kliniği İstanbul

Yazışma Adresi:

Tolga KARACAN

Istanbul Bağcılar Eğitim ve Araştırma

Hastanesi Istanbul - Türkiye

E posta: tolgakaracan84@gmail.com
\end{abstract}

Kabul Tarihi: 03 Nisan 2013

\section{Balıkesir Sağlık Bilimleri Dergisi \\ ISSN: 2146-9601 \\ e-ISSN: 2147-2238}

bsbd@balikesir.edu.tr www.bau-sbdergisi.com

\section{ÖZET}

Hamilelik sırasındaki delici travmalar günümüz şiddet toplumunda giderek artan bir problem haline gelmektedir. Delici travma sonucu fetal, plasental, kord ve intraabdominal organ hasarları rapor edilmiştir. Bu travmaların derecesinin belirlenip tedavisinin yapılması için sıklıkla eksploratif laparotomi gerekli olmaktadır. 26 yaşında gebe hasta ateşli silah yaralanması sonrası hastanemiz acil servisine getirildi. Operasyon odasında preoperatif olarak yapılan sonografi muayenesinde fetal kalp atımının ciddi bradikardik (30 atım/dk) ve uterusun koagulum ile dolu olduğu saptandı. Hasta acil olarak eksploratif laparotomi için operasyona alındı. Operasyon esnasında uterus sol round ligament etrafından aktif kanamalı bir adet küçük giriş deliği ve bir adet çıkış deliği gözlendi. Diğer batın içi organlarda herhangi bir yaralanma yoktu. Maternal vital bulguların stabilizasyonundan sonra sezaryen gerçekleştirildi ve 420 gr ölü fetus çıkarıldı. Uterin defektler primer olarak kapatıldı. Hasta operasyon sonrası altıncı gün taburcu edildi.

Anahtar Kelimeler: ateşli silah yaralanması, travma, delici yaralanma, gebelik, laparotomi

\begin{abstract}
SUMMARY
Penetrating trauma during pregnancy is an increasing problem in today's ever - violent society. Multiple direct fetal, placental, cord and intraabdominal organs injuries have been reported as a result of penetrating. Laparotomy is often required for determine the degree of trauma as well as treatment. A 26-year-old pregnant woman was brought into the emergency department of our hospital after suffering a gunshot wound. A preoperative transabdominal ultrasonography examination in the operating room determined that the fetal heart rate was severely bradycardic ( 30 beats/min) and the uterus was filled with coagulum. The patient was taken urgently to the operation for exploratory laparotomy. One bullet entry point was found at the root of the round ligament, and one bullet-exit point was at the posterior wall of the uterus and that site was actively bleeding. No injury was found to the other intraabdominal organs. After stabilization of the maternal vital signs, it was carried out a cesarean section and and a $420 \mathrm{~g}$ exanimate female fetus was taken out. The uterine defects were closed primarily. The patient was discharged on the 6 th postoperative day
\end{abstract}

Key words: gunshot wound, trauma, penetrating wound, pregnancy, laparotomy

\section{INTRODUCTION}

Trauma, murder, and other acts of violence are among the most common causes of death in young women; and about $10-20 \%$ of pregnant women are exposed to physical trauma at some point. Gunshot and knife wounds are the most frequently seen types of penetrating trauma, and may be associated with grievous assault, suicide attempts or attempted abortions. These can be fatal for both the mother and her baby, and treatment of pregnant women necessitates a particular approach, due to the physiological changes associated with pregnancy. Physiological and anatomical changes in pregnancy may mask or imitate the injury. The best method of treatment for the fetus is based on the appropriate resuscitation of the mother, and for this reason, the maternal well-being should be established first, after which fetal health may be evaluated.

This paper presents the case of a pregnancy in the 22ndweek of gestation that resulted in fetal death after the mother suffered a gunshot wound. Special attention was given to fetal and maternal treatment methods, and the most common errors in case management. 


\section{CASE REPORT}

A 26-year-old pregnant woman, who had previously given birth vaginally, was brought into the emergency department of our hospital after suffering a gunshot wound. According to the statements of patient's relatives, the patient was standing across from the attacker, and the wound was inflicted from close range. During the initial physical examination, which was performed immediately, the patient was unconscious, systolic blood pressure was $60 \mathrm{~mm} \mathrm{Hg}$, heart rate was 150/min, and no peripheral arterial pulse. An abdominal examination revealed a bullet entry wound in the abdomen, $1 \mathrm{~cm}$ in diameter, that was suggested the abdominal penetrance, intersecting $3 \mathrm{~cm}$ to the left lateral side of the umbilicus and midclavicular line, with no active bleeding or irregular wound edges. There were two more bullet-entry sites, one in the right hip, one in the right thigh. Immediately the patient was taken to the operating room. A preoperative trans-abdominal ultrasonographic examination was performed in the operating room. The fetal heart rate was severely bradycardic (30 beats $/ \mathrm{min}$ ), the uterus was filled with coagulum, and the patient had active vaginal bleeding. She was operated under intratracheal general anesthesia by surgeons from the obstetrics and gynecology and general surgery departments. A neonatal care specialist was present in the operating room to care for the baby. A laparotomy was performed through an infra-umbilical midline incision. Upon exploration, no injury was found to the liver, spleen, small bowel or colon, however there was approximately $500 \mathrm{ml}$ of hemorrhagic fluid in the peritoneum. The size of the uterus was compatible with 20-22nd-week of gestation. One bullet entry point was found at the root of the round ligament, and one bulletexit point was at the posterior wall of the uterus and that site was actively bleeding (Figures 1 and 2). it was decided to carry out a Cesarean section, and a $420 \mathrm{~g}$ exanimate female fetus was taken out through a $3 \mathrm{~cm}$ vertical incision in the lower uterine segment (Figure 3). No direct trauma to the fetus was present; however, there was a $70-80 \%$ placental abruption. The vertical uterine incision was closed in two layers using a No. 1 vicryl suture, and the uterine defects were closed primarily using the same suture material. After cleaning the intra-peritoneal cavity, the abdominal layers were closed appropriately and the operation was terminated.
Figure 1.

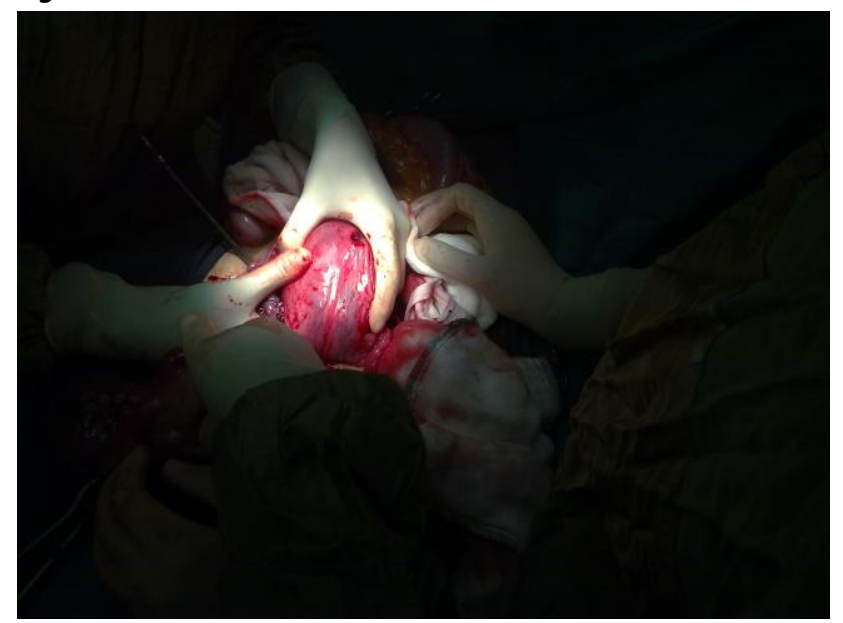

Figure 2.

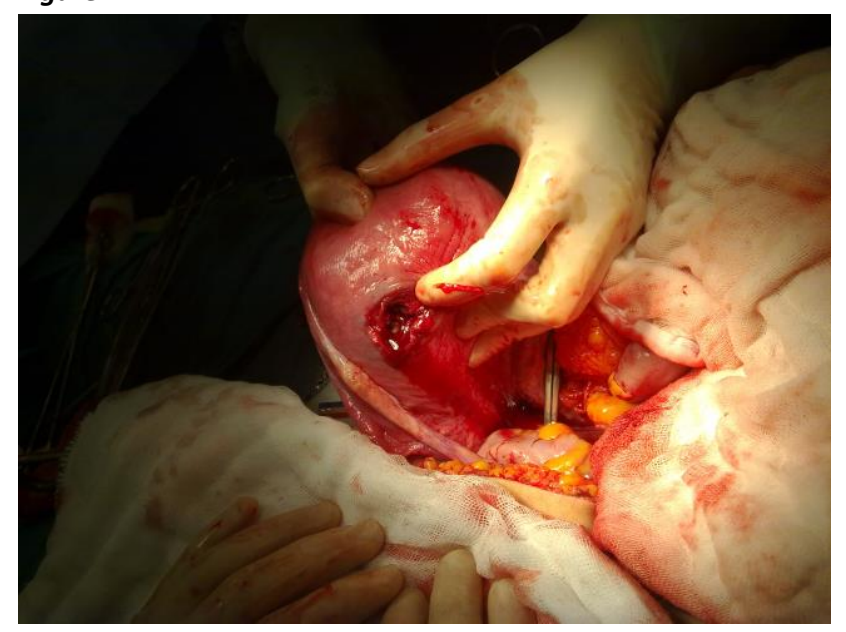

Two units of erythrocyte suspensions were transfused intra-operatively. The time interval between the entry of the patient into the emergency room and the closing of the abdominal incision was approximately 30 minutes. The time between the injury and admittance to the hospital could not be clarified. The postoperative hematocrit levels were stable and the patient's diuresis was normal. One dose of tetanus toxoid $(0.5 \mathrm{ml})$ and a $250 \mathrm{U}$ tetanus immunoglobulin was administered. For lactation inhibition, $1 \mathrm{mg}$ of cabergoline was administered orally on the first postoperative day. The postoperative period was unevetful and the patient was discharged on the 6th postoperative day. She was well on the follow-up visit at one month after the operation. Pathologic examination of the specimens revealed a female fetus compatible with a gestational age of 22ndweek and the placenta showed subchorionic hematoma as well as intervillous fibrin deposition. 
Figure 3.

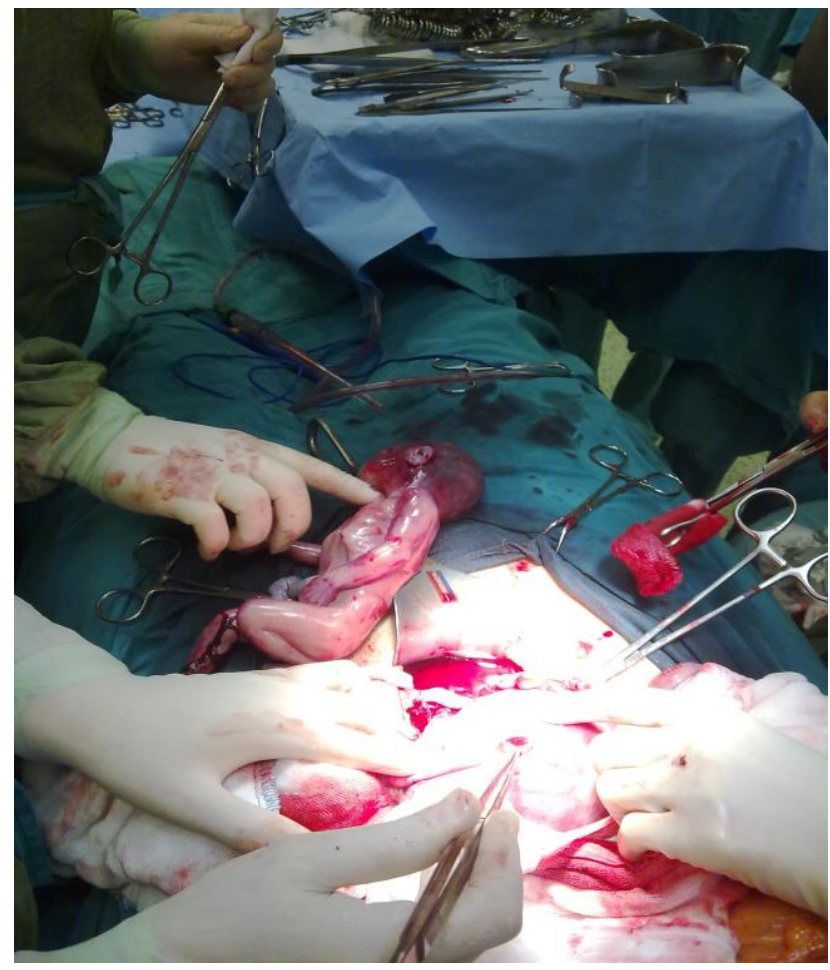

\section{DISCUSSION}

Physiological and anatomical changes in the organ systems of a pregnant woman exposed to trauma affect the symptoms and signs of injury and the results of diagnostic tests. Abdominal gunshot wounds carry high morbidity and mortality rates, in spite of developments in the treatment of such wounds. The major problem with such traumas is that bullets with high mechanic and kinetic energy, while progressing through the abdomen, damage the surrounding tissue due to the blast effect.

A pregnant uterus grows across the peritoneal cavity according to the gestational week, and causes the displacement of visceral organs, especially the intestines. In addition, the intact and dense muscular tissue of the uterus absorbs most of the bullet's energy and decreases the blast effect on the other intra-abdominal organs. Amniotic fluid contributes to the effects by passing the energy and pressure exerted on itself to the uterus in a decreased and diffusely disseminated manner. ${ }^{1}$ For this reason, the maternal visceral organ damage rate is low, around $19-38 \%$, in cases of penetrating trauma, while this rate is $80-90 \%$ in non-pregnant women. ${ }^{8}$

The most commonly encountered traumas in pregnancy are blunt abdominal traumas, accounting for around $70 \%$ of the total injuries, and most occurring during motor vehicle accidents. Incidences of penetrating traumas are fewer in these types of injuries. ${ }^{9}$ When a penetrating trauma occurs in a pregnant woman, there is a higher risk of severe injury to the fetus than the mother. Although fetal injury occurs in $2 / 3$ of these types of injuries, maternal visceral organ injuries occur in only $20 \%$ of cases. Petrone $\mathrm{P}$. et al. recorded a fetal mortality and a maternal mortality rate of $73 \%$ and $66 \%$, respectively, in 321 pregnant women who suffered blunt or penetrating traumas, and demonstrated that penetrating traumas constituted a higher risk than blunt traumas. ${ }^{6}$ KadyDe. et al., in a retrospective evaluation of penetrating abdominal traumas, identified gunshot wounds as the most commonly seen injury, with maternal death occurring in at least $5 \%$ of cases involving penetrating trauma. Fetal injuries occur in more than $70 \%$ of such cases, and unfortunately $40-70 \%$ of these result in fetal death. Fetal mortality may be a result of direct fetal damage or preterm birth, with the main factors affecting survival being gestational age, uterine perfusions, and thus oxygen levels. ${ }^{3}$ In the etiology of preterm births due to minor trauma, direct or indirect traumas resulting in uterine damage are thought to be based on the release of decidual lysosomes, and thus free arachidonic acid, resulting in uterine contractions. ${ }^{3}$

The management of trauma during pregnancy requires an interdisciplinary approach, involving specialists in general surgery, emergency medicine, obstetrics and gynecology, and anesthesiology. The management of treatment is generally similar to that of non-pregnant patients; however the effect of the physiological changes associated with pregnancy on the hemodynamics of the patient should be considered, and special circumstances, such as preterm births, ablatio placenta, feto-maternal hemorrhaging, and pregnancy loss related to trauma should be expected. ${ }^{2,9}$ The primary target for treatment is the evaluation and treatment of maternal wounds, followed by an evaluation of the fetus. The basic rule is resuscitation, including ventilation, stopping the bleeding, and treatment of hypovolemia with crystalloids and blood products.

The heart rate progressively increases during pregnancy, in accordance with the gestational age, and reaches 1520 beats/minute more than normal in the second and third trimester. In addition, decrease in blood pressure is 
at its maximum level in the second trimester, and the systolic-diastolic blood pressure is decreased by $5-10 \mathrm{~mm}$ $\mathrm{Hg}$. These changes should be considered when evaluating the tachycardic response to hypovolemia. In the management of a pregnant patient, it is vital that the enlarged uterus be positioned away from any large vessels, thus removing its effect on cardiac output. Following emergency resuscitation, fractures, internal organ injuries, bleeding areas, and placental, uterine and fetal injuries are evaluated. One of the most frequent errors is to focus on the status of the fetus during the emergency assessment, which may lead to lifethreatening injuries in the mother being overlooked. Another very important factor is the presence of amniotic fluid embolus, which can present with the sudden onset of respiratory symptoms and disseminated intravascular coagulation, with or without the presence of right heart failure. ${ }^{4}$

A laparotomy is the most commonly used procedure during the early period, and can aid in detecting and treating accompanying intra-abdominal injuries. ${ }^{7}$ In the presence of a penetrating abdominal trauma, the conventional approach is mandatory explorative surgery; however, recent studies suggest a conservative approach, with entry sites below the uterine fundus with anterior abdominal entry sites if the fetus is dead and the maternal evaluation is satisfactory. ${ }^{5,8}$ (normal vital signs, stable hematocrit, no bleeding in gastrointestinal and urinary systems) The risks of conservative management are related to coagulopathy and intrauterine infection, and the patient should be monitored closely in such cases, with fibrinogene levels and coagulation parameters monitored accordingly. Following a gunshot wound, the first step is a mandatory explorative laparotomy. A Cesarean section should be performed only if the uterus is preventing an adequate exploration, if the fetus is viable or if intra-uterine damage is suspected. ${ }^{8}$ In this case, maternal instability was present, and thus an emergent laparotomy was performed. There was no visceral organ damage other than the pregnant uterus. Although the fetus was immature, a Cesarean section was performed due to the intra-uterine injury, assessed after monitoring the vital signs, and after the bullet entry sites in the uterus were primarily repaired. In conclusion, violence is increasing in society with each passing day, and unfortunately trauma, murder, and similar violent attacks are among the most common causes of death in pregnant women. Without a doubt, developments in obstetrical science positively affect the management of pregnant women. A special approach to pregnant women exposed to trauma should be undertaken and correct medical precautions should be taken when necessary. Rh incompatibility should be assessed and tetanus prophylaxis should be performed appropriately. Since there is only a little information on trauma scoring system in pregnant patients, new studies on this area are needed.

\section{REFERENCES}

1. Peters CE, Sebourn CL. Wound ballistics of unstable projectiles. Part II: temporary cavity formation and tissue damage. J Trauma 1996; 40: 16-21.

2. Pearlman MD, Tintinalli JE. Evaluation and treatment of the gravida and fetus following trauma during pregnancy. Obstet Gynecol Clin North Am. 1991; 18: 371-81.

3. Kady DE, Gilbert WM, Anderson J ve ark. Trauma during pregnancy: an analysis of maternal and fetal outcomes in a large population. Am J Obstet Gynecol. 2004; 190: 1661-8.

4. Judich A, Kuriansky J, Engelberg I ve ark. Amniotic fluid embolism following blunt abdominal trauma in pregnancy. Injury. 1998; 29: 475-7.

5. Weintraub AY, Leron E, Mazor M. The pathophysiology of trauma in pregnancy: a review. J Matern Fetal Neonatal Med. 2006; 19: 6015.

6. Petrone $\mathrm{P}$, Talving $\mathrm{P}$, Browder $\mathrm{T}$ ve ark. Abdominal injuries in pregnancy: a 155-month study at two level 1 trauma centers. Injury. 2011; 42: 47-9.

7. Tokat AO, Karasu S, Barlas AM ve ark. The Diaphragmatic Injuries Due to Penetrating Thoracic Trauma. Türkiye Klinikleri Arch Lung 2011; 12: 48-53

8. Gungor ES, Sen S, Uzunlar O ve ark. Gunshot wound in pregnancy. Saudi Med J. 2006; 27: 1069-70

9. Guneysel O, Yesil O, Ozturk TC ve ark. Perimortem caesarean section following maternal gunshot wounds. J Res Med Sci. 2011; 16: 1089-91. 